\title{
Treatability Variance Petition for SRS Raschig Ring Packing Material
}

by

T. Hagstrom

Westinghouse Savannah River Company

Savannah River Site

Aiken, South Carolina 29808

BAT Associates

GA USA

This paper was prepared in connection with work done under the above contract number with the U.S. Department of Energy. By acceptance of this paper, the publisher and/or recipient acknowledges the U.S. Government's right to retain a nonexclusive, royalty-free license in and to any copyright covering this paper, along with the right to reproduce and to authorize others to reproduce all or part of the copyrighted paper. 


\section{DISCLAIMER}

This report was prepared as an account of work sponsored by an agency of the United States Government. Neither the United States Government nor any agency thereof, nor any of their employees, makes any warranty, express or implied, or assumes any legal liability or responsibility for the accuracy, completeness, or usefulness of any information, apparatus, product, or process disclosed, or represents that its use would not infringe privately owned rights. Reference herein to any specific commercial product, process, or service by trade name, trademark, manufacturer, or otherwise does not necessarily constitute or imply its endorsement, recommendation, or favoring by the United States Government or any agency thereof. The views and opinions of authors expressed herein do not necessarily state or reflect those of the United States Government or any agency thereof.

This report has been reproduced directly from the best available copy.

Available to DOE and DOE contractors from the Office of Scientific and Technical Information, P. O. Box 62, Oak Ridge, TN 37831; prices available from (423) 576-8401.

Available to the public from the National Technical Information Service, U. S. Department of Commerce, 5285 Port Royal Road, Springfield, VA 22161. 


\section{DISCLAIMER}

Portions of this document may be illegible in electronic image products. Images are produced from the best available original document. 
WSRC-RP-99-00649.

AUGUST 4, 1999

\section{Treatability Variance Petition FOR SRS RASCHIG RING PACKING MATERIAL (U)}
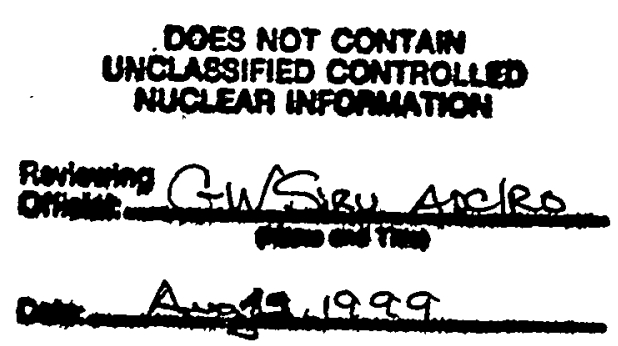

Westinghouse Savannah River Company Savannah River Site Aiken, SC 29808

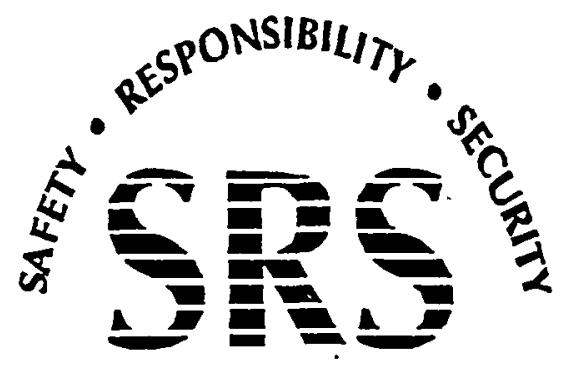

SAVANNAH RIVER SITE

Prepared by: BAT Associates, Inc. 


\section{DISCLAIMER}

This report was prepared by BAT Associates, Incorporated for Westinghouse Savannah River Company (WSRC) under Contract No. C001168P Task 24 and is an account of work performed under that contract. Reference herein to any specific commercial product, process, or services by trademark, name, manufacturer or otherwise does not necessarily constitute or imply endorsement, recommendation, or favoring of same by BAT Associates, Inc, WSRC or by the United States Government or any agency thereof.

\begin{tabular}{|c|}
\hline $\begin{array}{c}\text { Printed in the United States of America } \\
\text { Prepared for }\end{array}$ \\
Westinghouse Savannah River Company \\
by \\
BAT Associates, Incorporated \\
5151 Brook Hollow Parkway \\
Suite 250 \\
Norcross, Georgia
\end{tabular}




\title{
TREATABILITY VARIANCE PETITION FOR SRS RASCHIG RING PACKING MATERIAL
}

\author{
EXECUTIVE SUMMARY
}

The Department of Energy's (DOE) Savannah River Site (SRS) is a vital component in the nation's nuclear weapons complex. When in full operation, SRS produced nuclear material by manufacturing fuel and target components that were then irradiated in nuclear reactors. The fuel. and target components were manufactured and assembled in $\mathrm{M}$ Area. The components were then transferred and loaded into production reactors in $\mathrm{C}, \mathrm{K}, \mathrm{L}, \mathrm{P}$, and $\mathrm{R}$ Areas for irradiation. Once irradiated, the components were transported by shielded railroad cars to either $\mathrm{F}$ or $\mathrm{H}$ Area for recovery of nuclear matẻrials.

Liquid-liquid extraction and purification of the desired nuclear materials from the irradiated fuel rods and targets were performed at the Separations facilities in $F$ and $H$ Areas using the Plutonium Uranium Extraction (PUREX) process. In $\mathrm{H}$ Area, the PUREX process was later modified for nuclear safety reasons and named HM (acronym for "H modified").

Several safety features were incorporated in $\mathrm{H}$ Area. when the Separations facility was converted from PUREX to HM, including the removal of equipment and pipe connections that could contribute to inadvertent transfers of materials. In addition, because the H-Area A-Line sumps were not critically safe in configuration, the sumps were packed with neutron-absorbing Raschig rings made of a homogeneous mixture of metals distributed through an organic matrix. Cadmium (approximately $20 \%$ by weight), lead (approximately $20 \%$ by weight), and other trace metals are dispersed throughout the rubbery plastic ring. Any known spills or leaks of uranyl nitrate solutions in the A-Line area and B-3 basin were flushed to the appropriate sump and processed through the General Purpose (GP) evaporator to avoid accumulation and possible precipitation.

The Raschig ring material is known to be characteristically hazardous for cadmium (D006) because of analyses performed on the waste stream. Laboratory analysis of Raschig ring samples indicated that the organic matrix material contains sufficient cadmium to yield a Toxicity Characteristic Leaching Procedure (TCLP) leachate above the characteristic level. Lead and several trace metals were also indicated, but fell below characteristic levels during TCLP testing. Therefore, the Raschig rings are D006 waste, and are identified in the SRS Site Treatment Plan (STP) as Waste Stream SR-W073, "Plastic/Lead/Cadmium Raschig rings." The spent rings may also be contaminated with the various radionuclides present in the process solutions.

The land disposal restrictions (LDRs) require treatment of hazardous wastes to specified concentrations or by specified technologies prior to their ultimate disposition. The treatment standard for non-wastewater forms of D006 waste was set at the characteristic level of $0.11 \mathrm{mg} / \mathrm{L}$ in the TCLP extract. In setting the concentration-based standards, the Environmental Protection Agency (EPA) relied upon the performance of certain treatment processes defined as Best Demonstrated and Available Technologies (BDAT) for treatment of certain D006 nonwastewaters. The technologies considered as BDAT for D006 non-wastewaters were stabilization 
(other than cadmium-containing batteries), high-temperature metals recovery, chemical precipitation, incineration, and cadmium recovery (from batteries).

Under 40 Code of Federal Regulations (CFR) 268.44(h), generators and treatment facilities may petition the EPA for a site-specific variance from the treatment standards where the standards are not appropriate to a subject waste stream. The petition must demonstrate that the wastes cannot be treated to meet the standards or that the technologies used to set the standards are inappropriate to the waste. Accordingly, Westinghouse Savannah River Company (WSRC) evaluated those technologies considered as BDAT for D006 for their appropriateness in treating the Raschig rings packing materials. This evaluation determined that the technologies were not appropriate to the Raschig ring packing material for several reasons. First, the unique chemical and physical properties of the rings differ significantly from the wastes considered in establishing stabilization as BDAF. Second, the cadmium is embedded in the matrix of the rings and would require the use of higher operating temperatures for removal or recovery, which could release unwanted species (such as radioactive contaminants). The cadmium may not be amenable to removal or recovery processes due to the matrix in which it is embedded. Third, the Raschig rings are contaminated with low levels of radioactive materials. Certain radionuclides have decomposition temperatures that are below those of cadmium. Accordingly, any attempt to thermally remove cadmium from the rings could generate a residue contaminated with various radionuclides, so it could not be considered suitable for further recovery.

The spent rings are similar to material commonly considered to be hazardous debris. They are inherently debris-like because they are solid, manufactured objects and are only slightly smaller $(51 \mathrm{~mm}$ to $55 \mathrm{~mm}$ ) than the required $60 \mathrm{~mm}$. Accordingly, WSRC investigated the application of debris-type technologies for treatment of the rings. Debris-type physical extraction, chemical extraction and destruction technologies were determined to be inappropriate because of the physical and chemical characteristics of the rings.

The proposed treatment presented in this petition involves the use of debris-type immobilization for the Raschig rings. Immobilization can be accomplished by several methods including, but not limited to, encapsulating the wastes within an inorganic jacket or encapsulating the waste with a surface-coating substance, such as a polymeric organic. The integrity of the macroencapsulation will be ensured by constructing or applying it in accordance with nationally recognized standards, conducting a non-destructive inspection of the macroencapsulation after fabrication or application, and strict adherence to QA/QC procedures. Such treatment is consistent with the overall objective of the LDR treatment standards because it reduces the mobility of the waste. The proposed treatment meets the debris immobilization performance standards for resistance to degradation by the waste or environment. Furthermore, such treatment has been previously determined by EPA to be demonstrated for certain mixed wastes. Therefore, WSRC formally requests that EPA approve this site-specific variance from the LDR treatment standards for the Raschig rings. Submittal of this variance request is required by the SRS Approved STP. The STP was prepared pursuant to the Federal Facility Compliance Act of 1992. 


\section{TABLE OF CONTENTS}

List of Figures

List of Tables

iv

List of Acronyms

1.0 Identification of Applicant

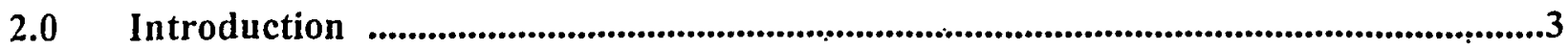

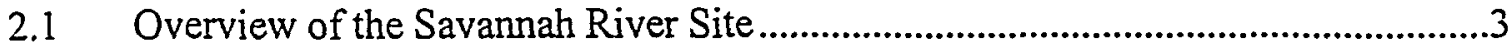

2.2 Description of the Waste Stream Subject to this Petition .....................................6

3.0 Regulatory Framework Relevant to this Petition .......................................................11

3.1 Regulatory Classification of the SRS Raschig Ring Packing Material .................11

3.2 LDR Standards Applicable to the SRS Raschig Ring Packing Material ...............13

3.3 Treatment Standards for D006 Wastes and BDAT Used ..................................14

4.0 Statement of the Petitioner's Interest in the Proposed Variance .................................15

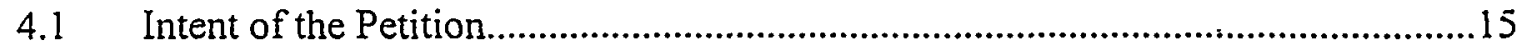

4.2 Summary of the Rationale for this Petition......................................................16

Characterization of the Waste Stream ................................................................19

5.1 Processes Generating Waste in H-Area ...........................................................19

5.2 Characteristics of the Waste Matrix ..................................................................19

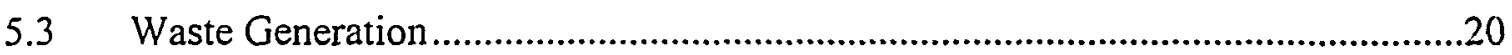

6.0 Demonstration that the SRS Raschig Rings Differ Significantly from the Wastes Used to Set the Treatment Standards .....................................................................21

6.1 Waste Composition..................................................................................21

6.2 Evaluation of SRS Raschig Ring with Respect to the D006 Standard ..................22

7.0 Proposed Alternative Standard and Treatment Process...............................................27

7.1 Encapsulation within a Cement Matrix..........................................................29

7.2 Encapsulation within a Polymer Matrix ...........................................................30

7.3 Immobilization within a Steel Jacket ..........................................................30

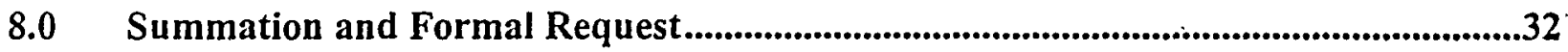

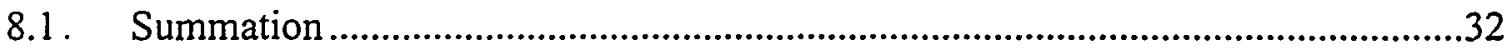

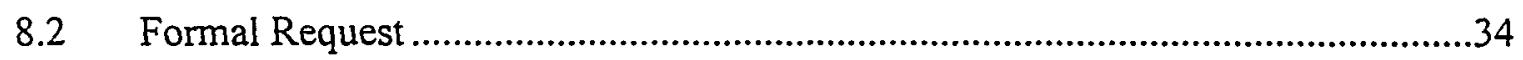

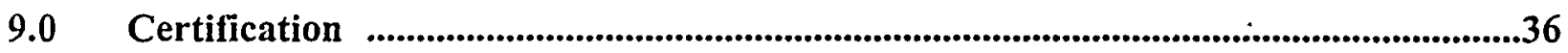

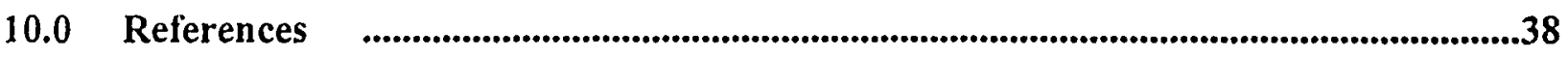




\section{LIST OF FIGURES}

Figure 2-1 Location of the Savannah River Site. 4

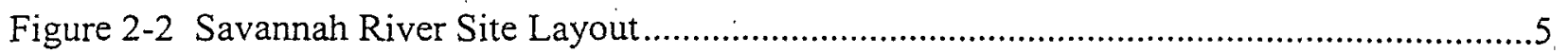

Figure 2-3 Photograph Showing Raschig Ring Diameter........................................................

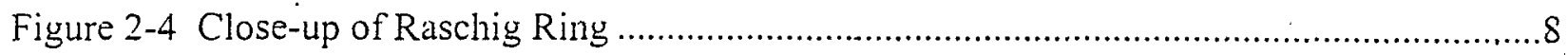

Figure 2-5 Collected Raschig Rings …….........................................................................

\section{LIST OF TABLES}

Table 6-1 TCLP Metals Analysis Results. 


\section{LIST OF ACRONYMS}

$\begin{array}{ll}\text { ALARA } & \text { As Low As Reasonably Achievable } \\ \text { BDAT } & \text { Best Demonstrated and Available Technology } \\ \text { BNFL } & \text { British Nuclear Fuel, Ltd. } \\ \text { CCW } & \text { Constituent Concentrations in Waste } \\ \text { CCWE } & \text { Constituent Concentrations in Waste Extract } \\ \text { CFR } & \text { Code of Federal Regulations } \\ \text { CIF } & \text { Consolidated Incinerator Facility } \\ \text { DOE } & \text { U.S. Department of Energy } \\ \text { DOE-SR } & \text { Department of Energy-Savannah River } \\ \text { DOT } & \text { U.S. Department of Transportation } \\ \text { EP } & \text { Extraction Procedure } \\ \text { EPA } & \text { U.S. Environmental Protection Agency } \\ \text { EUS } & \text { Enriched Uranium Storage } \\ \text { FR } & \text { Federal Register } \\ \text { GP } & \text { General Purpose Evaporator } \\ \text { HM } & \text { H Modified Process } \\ \text { HSWA } & \text { Hazardous and Solid Waste Amendments } \\ \text { LDR } & \text { Land Disposal Restrictions } \\ \text { NRC } & \text { Nuclear Regulatory Commission } \\ \text { PUREX } & \text { Plutonium Uranium Extraction } \\ \text { QA QC } & \text { Quality Assurance/Quality Control } \\ \text { RCRA } & \text { Resource Conservation and Recovery Act } \\ \text { SRS } & \text { Savannah River Site } \\ \text { STP } & \text { Site Treatment Plan } \\ \text { TCLP } & \text { Toxicity Characteristic Leaching Procedure } \\ \text { UNH } & \text { Uranyl Nitrate Hexahydrate } \\ \text { WSRC } & \text { Westinghouse Savannah River Company } \\ & \end{array}$


Treatability Variance Petition for SRS

WSRC-RP-94-00040

Raschig Ring Packing Matcrial

August 4 . 19\%)

This page intentionally left blank 


\subsection{IDENTIFICATION OF APPLICANT}

Petitioner's Name: $\quad$ United States Department of Energy

Savannah River Operations Office

Petitioner's Address: United States Department of Energy

Savannah River Operations Office

P.O. Box A

Aiken, SC 29808

EPA ID Number:

SCI8900008989

Facility Contact :

Mike Simmons

United States Department of Energy

Savannah River Operations Office ·

(803) 725-1627 
This page intentionally left blank. 


\section{2:0 INTRODUCTION}

This section provides a historical overview of the Savannah River Site, including location of the facility and facility operations. Figures showing the site location and site layout are included. In addition, photographs taken during sampling of the Raschig rings are provided.

\subsection{OVERVIEW OF THE SAVANNAH RIVER SITE}

The Savannah River Site (SRS) was established in 1950 by the United States Atomic Energy Commission and is part of the United States Department of Energy (DOE) weapons complex. The site is owned and operated by the DOE and co-operated under contract by the Westinghouse Savannah River Company (WSRC). As shown in Figure 2-1, the site is located approximately 25 miles southeast of Augusta, Georgia, 18 miles south of Aiken, South Carolina, and 100 miles west of the Atlantic Ocean. The Savannah River borders the SRS on the southwest. The site consists of 15 areas within a 310 square mile area located in Aiken, Barnwell, and Allendale counties, South Carolina. The site layout is shown in Figure 2-2.

Historically, the site's primary function has been the production and recovery of nuclear materials (primarily tritium, $\mathrm{Pu}-239$ and enriched uranium) for national defense purposes. In addition, SRS has produced special nuclear materials for medical and space programs. Such materials have included $\mathrm{Pu}-238$, which has been used in radioisotopic thermal generators that provide electrical power for space missions.

When in full operation, SRS produced nuclear material by manufacturing fuel and target components that were then irradiated in nuclear reactors. The fuel and target components were manufactured and assembled in $M$ Area. The components were then transferred and loaded into production reactors in $\mathrm{C}, \mathrm{K}, \mathrm{L}, \mathrm{P}$, and $\mathrm{R}$ Areas for irradiation. Once irradiated, the components were transported by shielded railroad cars to either $\mathrm{F}$ or $\mathrm{H}$ Area for recovery of nuclear materials.

Liquid-liquid extraction and purification of the desired nuclear materials from the irradiated fuel rods and targets were performed at the Separations facilities in $\mathrm{F}$ and $\mathrm{H}$ Areas. The primary nuclear materials products obtained from the Separations facilities were Pu-239 and U-238. These products were obtained by dissolving irradiated depleted uranium targets or plutonium/aluminum alloy charges in nitric acid, followed by separation of the desired materials using the Plutonium Uranium Extraction (PUREX) process.

The initial stages of this process involved a series of contactors that provided separation of the uranium and plutonium from the waste activation and fission product isotopes. Subsequent stages of the PUREX process separated plutonium from the uranium and purified both product streams. The product streams were either transferred to other DOE facilities for further processing or returned to $\mathrm{M}$ Area for reuse in target fabrication. 


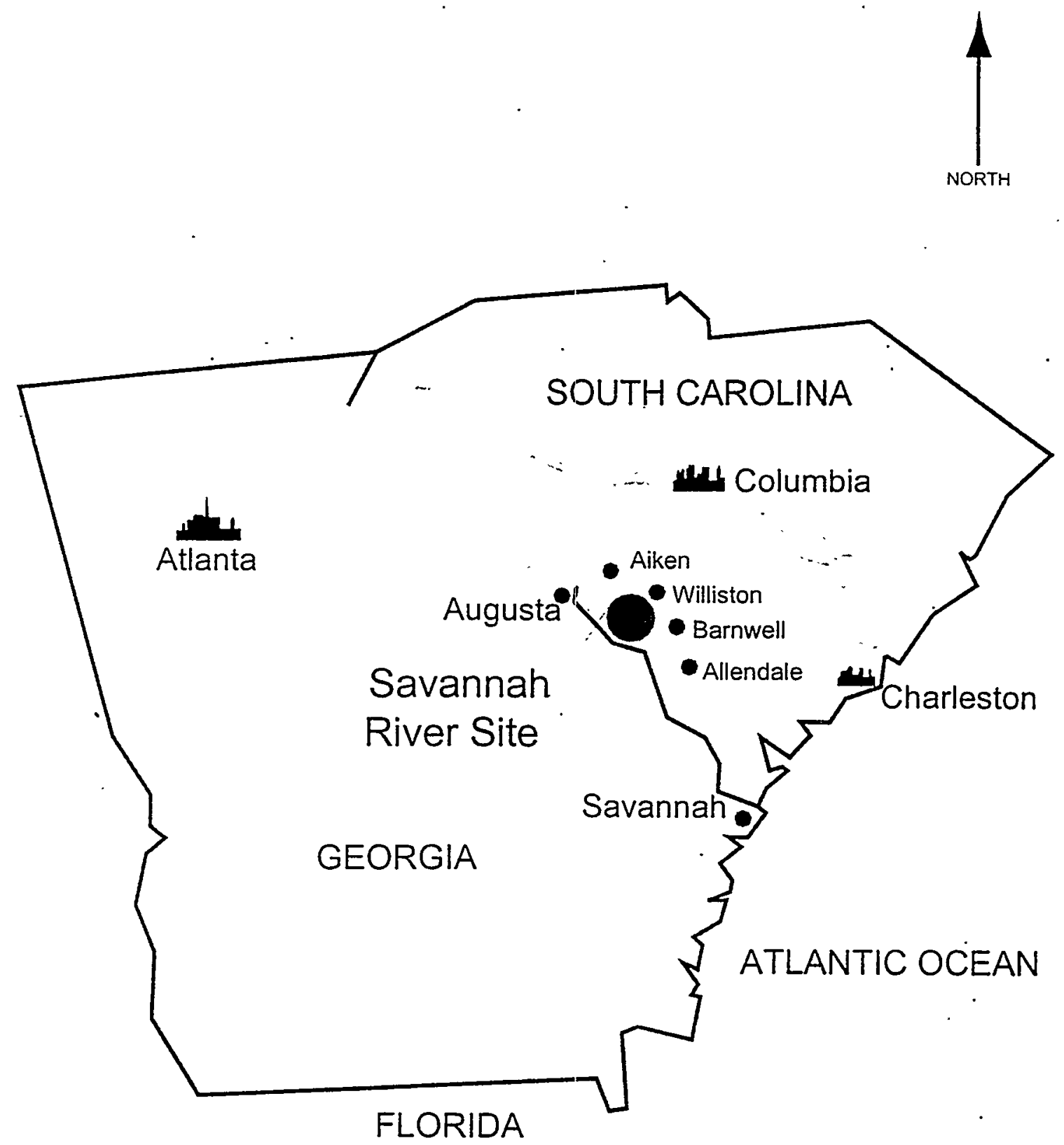

Figure 2-1

Location Map

Department of Energy Savannah River Site 


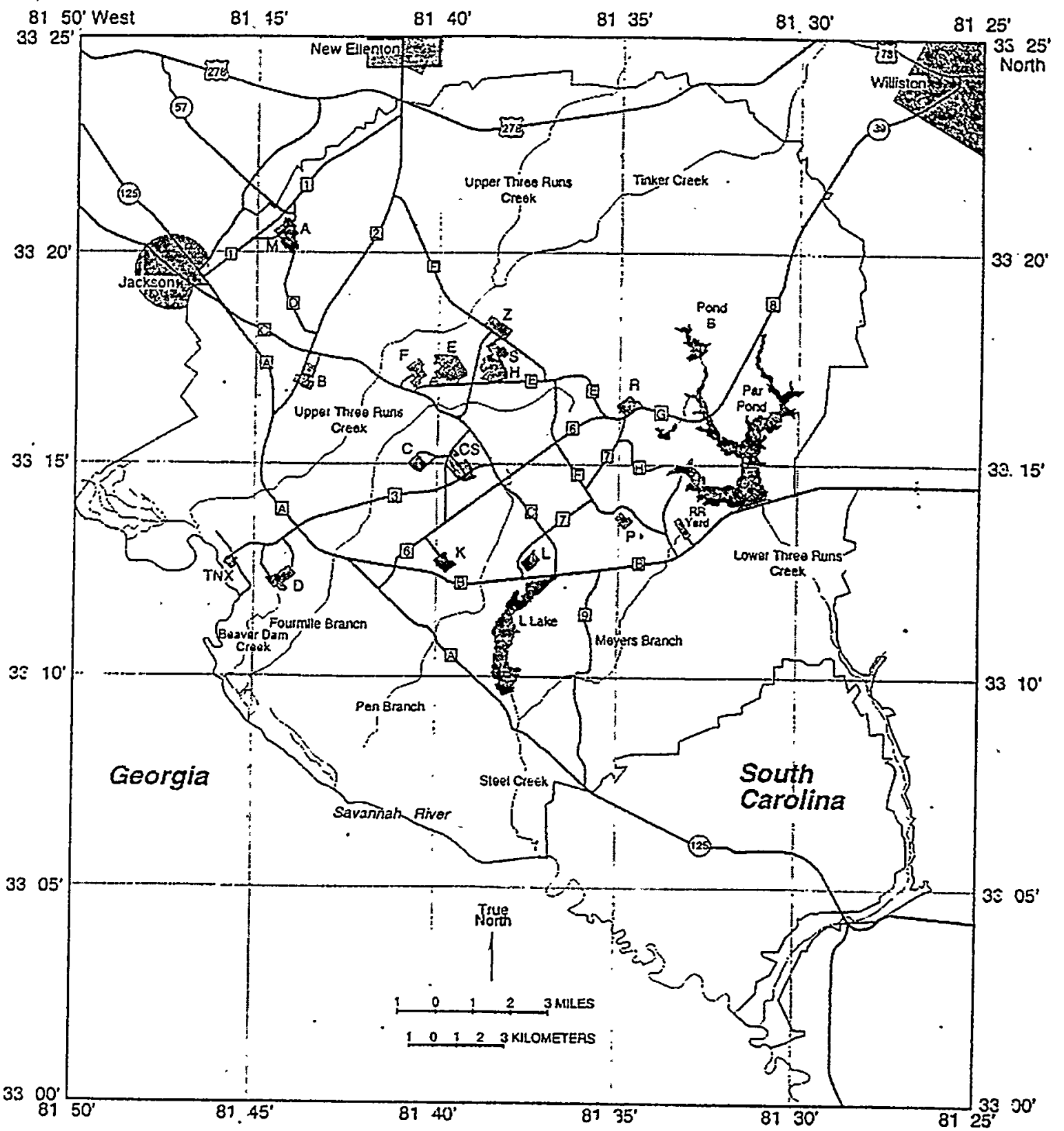

Figure 2-2

Site Layout

Department of Energy Savannah River Site 
The PUREX process was modified and named HM (acronym for "H modified") to limit the concentrations of the uranium product because the available facilities were not geometrically favorable for nuclear criticality control when dealing with large quantities of enriched uranium. The HM process is used for irradiated uranium fuels that contain from 1.1 to $94 \%$ U-235. Using this modified process, the H-Area Separations facility recovered enriched U-235 from spent fuel rods generated in the production reactors by dissolution in nitric acid followed by separation of U-235 from the waste fission products. The initial stages of the H-Area process also involved separation of the byproduct $\mathrm{Np}-237$, which was subsequently converted to its oxide and irradiated to yield Pu-238.

In addition to $\mathrm{U}-235$ and $\mathrm{Pu}-238, \mathrm{H}$ Area produced tritium by extracting light isotope gases from irradiated lithium/aluminum targets. In this process, the irradiated targets were heated under vacuum to cause evolution of deuterium, tritium and helium isotopes that were subsequently separated by diffusion and exchange processes.

Several safety features were incorporated in $\mathrm{H}$ Area when the Separations facility was converted from PUREX to HM, including the removal of equipment and pipe connections that could contribute to inadvertent transfers of materials. In addition, because the H-Area A-Line sumps were not critically safe in configuration, the sumps were packed with neutron-absorbing Raschig rings made of a mixture of metals, primarily cadmium and lead, dispersed in a rubbery plastic matrix.

\subsection{DESCRIPTION OF THE WASTE STREAM SUBJECT TO THIS PETITION}

This section presents an overview of the wastes that are the subject of this treatability variance petition and the processes from which the wastes were derived. Photographs of Raschig rings are also provided. Details of the generating processes and characteristics of the wastes are presented in Section 5.0.

\subsubsection{Waste Stream Process}

Separation processes in $\mathrm{H}$ Area include the dissolution of nuclear materials from the production reactors or other sources. After the dissolution, the materials are processed through the HM process to remove the fission products and other waste materials. One part of the process, called the Second Uranium Cycle, produces uranyl nitrate hexahydrate (UNH) solution, which is transferred to the A-Line facility for storage.

All A-Line Tanks are located within secondary containment dikes with sumps for collecting leaks. By A-Line operating procedure, any known spills or leaks are flushed to the appropriate sump and processed through the General Purpose (GP) evaporator to avoid accumulation and possible precipitation. The sumps in H-Area A-Line are not critically safe in configuration. Therefore, the sumps were previously packed with neutron-absorbing Raschig rings to prevent the accumulation of a critical mass of material in the sumps. Photographs of the Raschig rings 
used in the sumps are shown in Figures 2-3, 2-4, and 2-5. The Raschig rings in the sumps may have potentially been contaminated with UNH from a spill or leak.

UNH solution was previously transferred to Oak Ridge for further processing. When these transfers ceased, the Enriched Uranium Storage (EUS) tank was constructed for long-term storage. Leaks or spills from the EUS tank enter the spill containment annulus and are recycled back to the tank. UNH is stored only in the EUS tank. Tanks previously used for UNH have either been taken out of service or placed in use for other materials. With the tank change, the Raschig rings were no longer necessary because the sump did not have the same potential for accumulation, and the rings were removed.

\subsubsection{Waste Composition}

The Raschig rings (Figures 2-3, 2-4, and 2-5) are composed of a mixture of metals dispersed throughout an organic matrix. The primary metals in the rubbery plastic matrix are cadmium and lead. Cadmium is the neutron absorber and is approximately $20 \%$ of the weight of the ring. Lead composes approximately $20 \%$ of the weight and increases the specific gravity to greater than 1.5 to prevent the rings from floating in high-density solutions. Traces of other metals in low concentrations are also dispersed throughout the ring matrix.

In addition, the rings are also contaminated with very low concentrations of uranium, plutonium, and mixed fission or activation product isotopes such as Cs-137, Co-60, Sr-90, Nb-95, Ru-103, and $\mathrm{Ce}-144$. This contamination by these radionuclides occurred during the collection of minor leaks or spills in the A-Line sumps in which the rings were placed. The presence of radioactive materials makes the Raschig rings a mixed waste.

The composition of the waste matrix is further discussed in Section 5.0. In addition, a discussion is provided on the characteristics of the Raschig rings, including waste management considerations.

The current inventory of Raschig rings stored at SRS is $1.8 \mathrm{~m}^{3}$. The material was generated as a one-time waste. The rings are no longer necessary in the sump. Therefore, no future generation of this waste is anticipated. The waste is currently contained within plastic bags inside drum liners in nine loosely packed 55-gallon drums awaiting treatment and disposal. 


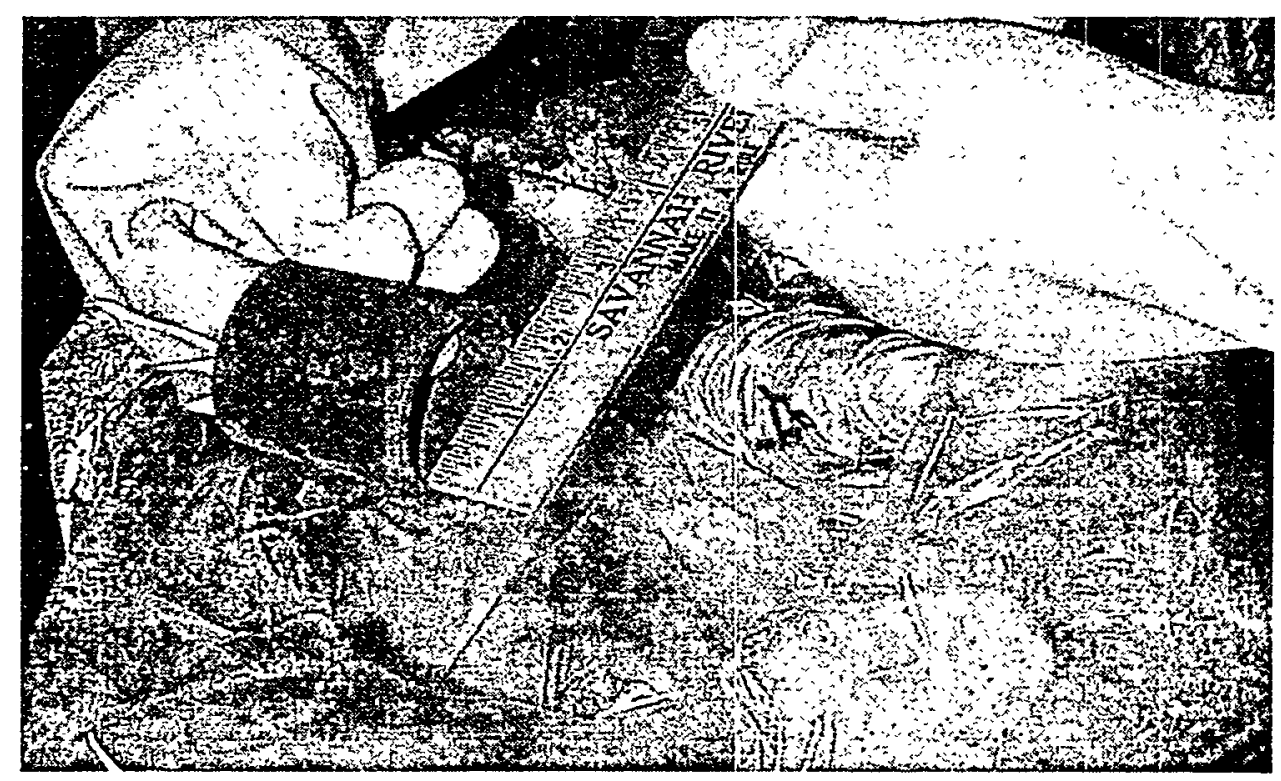

Figure 2-3 Photograph Showing Raschig Ring Diameter

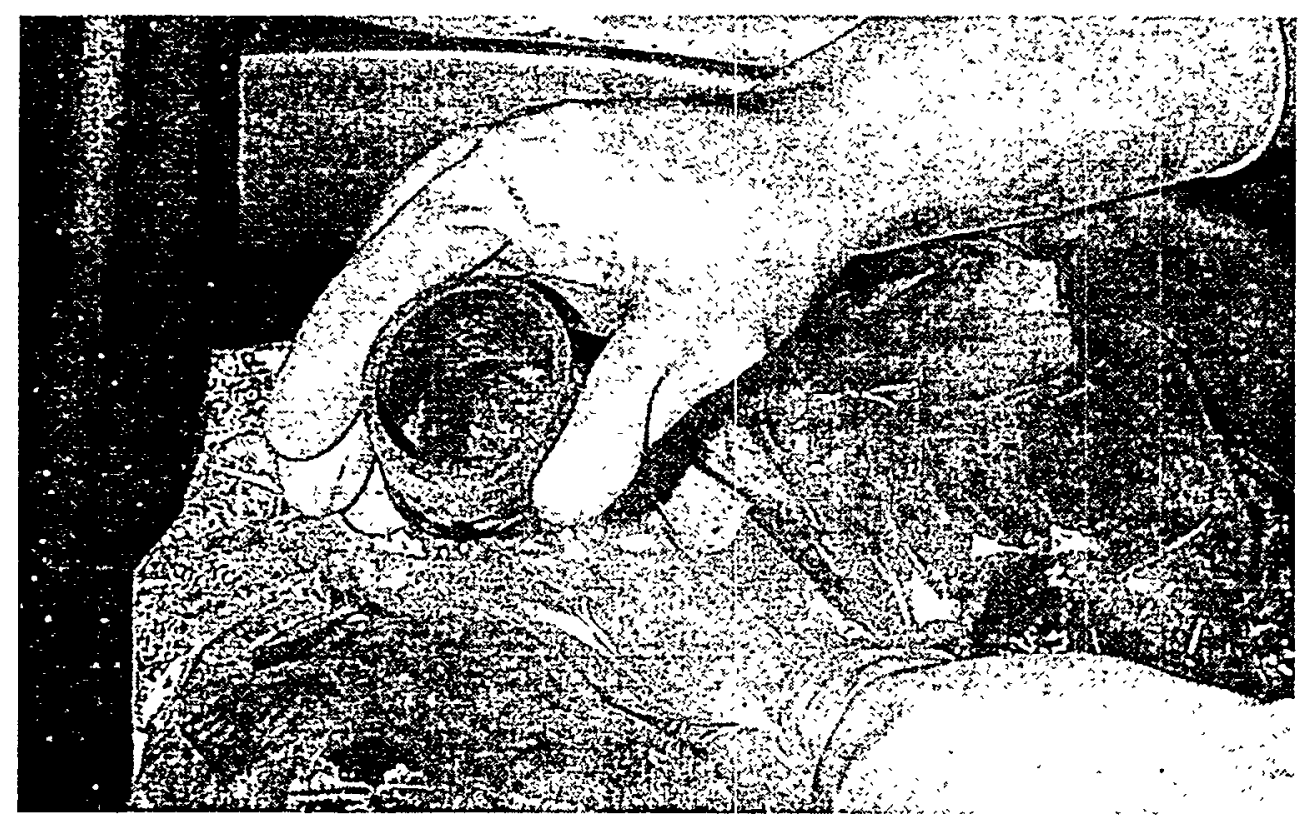

Figure 2-4 Close-up of Raschig Ring 


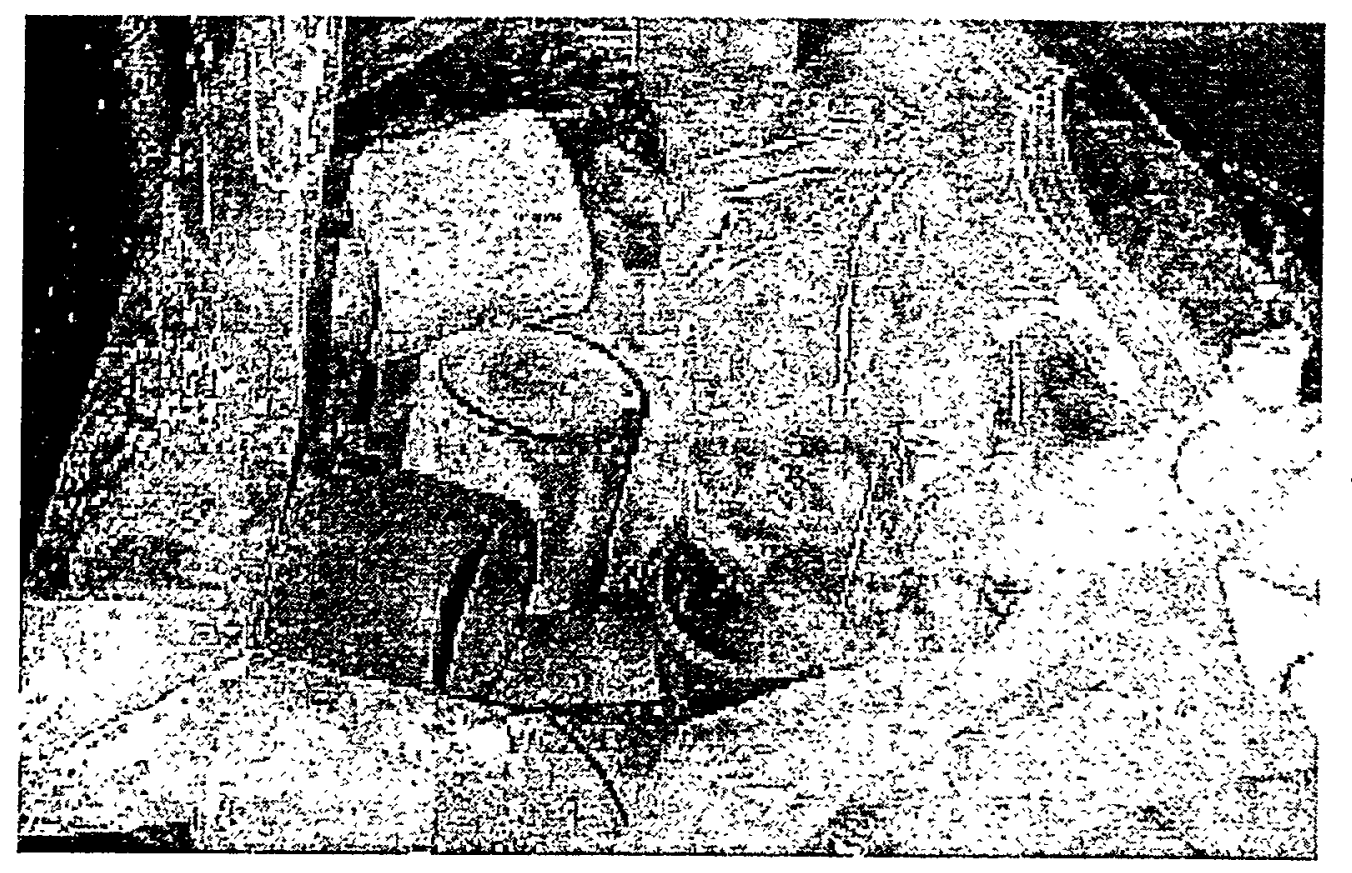

Figure 2-5 Collected Raschig Rings 
This page intentionally left blank. 


\subsection{REGULATORY FRAMEWORK RELEVANT TO THIS PETITION}

This section provides a detailed discussion of the Resource Conservation and Recovery Act (RCRA) regulations applicable to the neutron-absorbing Raschig ring packing material generated by SRS. This includes the relevant portions of 40 Code of Federal Regulations (CFR) Parts 261 and 268. Also included in this section is a discussion of the radiological characteristics associated with the waste that impact waste treatability. All discussions of regulatory citations reference the regulations found in 40 CFR and 55 FR 22520.

\subsection{REGULATORY CLASSIFICATION OF THE SRS RASCHIG RING PACKING MATERIAL}

The following sections discuss applicable RCRA classifications for the SRS Raschig rings. RCRA solid waste characterization, RCRA hazardous waste characterization, and additional characterizations under RCRA are defined.

\subsubsection{RCRA Solid Waste Characterization}

To determine which Land Disposal Restrictions (LDR) are applicable to the Raschig rings yenerated at SRS, the nature of the rings must be defined as specified in 40 CFR 261.2 and 40 CFR 261.3. The regulations in 40 CFR.261.1 state:

"A spent material is any material that has been used and as a result of contamination can no longer serve the purpose for which it was produced without processing...."

The Raschig rings are a "spent material" as defined in 40 CFR 261.1 because they were used as a neutron-absorbing media and, as a result of use, became contaminated with radioisotopes. In addition, the rings contain cadmium, lead and other trace metals embedded in the organic matrix. The rings have been removed from the process and containerized pending treatment and disposal.

The requirement in 40 CFR 261.2 states that a material is a solid waste if it is discarded by being abandoned, recycled, or is inherently waste-like. The Raschig rings are abandoned by being stored prior to disposal and are therefore a solid waste according to 40 CFR 261.2(b)(3) which states:

"Materials are solid waste if they are abandoned by being accumulated, stored, or treated (but not recycled) before or in lieu of being abandoned by being disposed of, burned, or incinerated."

In summary, the Raschig rings are spent materials that are contaminated with radioisotopes and contain heavy metals (i.e., cadmium and lead). The Raschig rings are also solid wastes because they are being stored prior to disposal. 


\subsubsection{RCRA Hazardous Waste Characterization}

40 CFR 262.11 requires that a person generating a solid waste as defined in 40 CFR 261.2 must determine whether the solid waste is also a hazardous waste. This is accomplished through the use of process knowledge or by testing the waste material to determine whether it exhibits a hazardous characteristic or is a listed hazardous waste. The determination of whether a solid waste is also a hazardous waste requires the application of the hazardous waste definition found in 40 CFR 261.3. This definition lists four specific examples of solid wastes that are also hazardous waste.

- Solid wastes that exhibit a hazardous characteristic (i.e., ignitability, corrosivity, reactivity, or toxicity characteristic);

- Solid wastes that meet the listing criteria of a listed hazardous waste (i.e., Fxxx, Kxxx, Uxxx, Pxxx);

- Wastes that are a mixture of solid waste and listed hazardous waste; or

- Wastes that are a mixture of solid waste and characteristic waste where the mixture exhibits a hazardous characteristic.

These criteria must be applied to wastes when making the hazardous waste determination required by 40 CFR 262.11 .

The first requirement of 40 CFR 262.11 is to determine whether the waste is excluded from regulation under 40 CFR 261.4. Exemptions include materials that are not solid waste [40CFR261.4(a)], solid wastes that are not hazardous wastes [40 CFR 261.4(b)], hazardous wastes which are exempt from certain regulations [40 CFR 261.4(c)], and sample exclusions [40 CFR 261.4 (d), (e), and (f)]. The SRS Raschig rings do not meet any of the exclusion criteria identified in these regulations.

The second requirement of 40 CFR 262.11 is to determine whether the solid waste is a hazardous waste as listed in Subpart D of 40 CFR 261. These waste listings include wastes from nonspecific sources, wastes from specific sources, and unused commercial chemical products or intermediates that are discarded. The SRS Raschig rings do not meet the listing description of any listed hazardous waste identified in Subpart D of 40 CFR 2961 (e.g., Fxxx, Kxxx, Uxxx, Pxxx).

The third requirement of 40 CFR 262.11 states that if the waste is not listed in Subpart D of 40 CFR 261, the generator must determine if the waste is identified in Subpart C of 40 CFR 261 (characteristic hazardous wastes) by either testing the waste in accordance with the methods set forth in subpart C of 40 CFR Part 261 (or use of an equivalent method approved by the EPA Administrator) or applying knowledge of the hazard characteristic of the waste in light of the materials or the process used. SRS performed sampling and analysis to determine the composition of the Raschig rings. Analytical results revealed the presence of heavy metals, primarily cadmium and lead, in the Raschig ring matrix. Cadmium is the neutron absorber and is 
approximately $20 \%$ of the weight of each ring. Lead also accounts for approximately $20 \%$ of the weight of each ring and increases the specific gravity to greater than 1.5 to prevent the rings from floating in high-density solutions. Trace metals and the organic matrix compose the remainder of the weight of the rings. A Toxicity Characteristic Leaching Procedure (TCLP) was performed to determine the leachability of any characteristically hazardous constituents. Cadmium was detected above regulatory levels. Lead and the other trace metals were detected below regulatory levels. Therefore, SRS has concluded that the Raschig rings are characteristically hazardous for cadmium and carry the RCRA waste code D006.

\subsubsection{Additional Characterizations under RCRA}

40 CFR 262.11 requires that tests be conducted to determine compliance with LDR found in 40 CFR Part 268. These requirements include treatment standards applicable to D006. waste material as promulgated by the EPA in the Federal Register (55 FR 22520). Additional requirements for man-made materials were promulgated in the Debris Rule (57 FR 37223). The Debris Rule promulgated specific treatment technologies for materials that met the criteria specified within the rule. The definition of debris that was added to 40 CFR Part 260 specifies that, in order for a material to be considered debris, it must be at least $60 \mathrm{~mm}$ (approximately 2.5 in.) in size. The Raschig rings utilized at SRS do not meet this criterion, as they are slightly less than $60 \mathrm{~mm}$ (i.e., $51 \mathrm{~mm}$ to $55 \mathrm{~mm}$ ). However, the Raschig rings are inherently debris-like. The rings are man-made and conform to other aspects of the debris definition. If considered debris due to its debris-like nature, the debris treatment technologies specified in the rule could be applied to the Raschig rings.

If not treated as debris, the preamble to the rule states that materials that do not meet the minimum size criteria must be treated to the treatment standards or by the best demonstrated available technology (BDAT) specified in the LDRs. That is, the Raschig rings must be treated as cadmium waste since the waste has applicable treatment standards specified with the LDRs in 40 CFR Part 268.

\subsection{LDR STANDARDS APPLICABLE TO THE SRS RASCHIG RING PACKING MATERIAL}

The LDRs are required by the Hazardous and Solid Waste Amendments (HSWA) of 1984 and identify treatment standards expressed in constituent concentrations or BDAT. These standards are applicable to all prohibited hazardous wastes identified in 40 CFR Part 268. The prohibited wastes that have standards expressed as a concentration in the waste or waste extract are additionally subdivided into wastewater and non-wastewater categories. The LDRs define wastewater as liquid wastes that contain less than $1 \%$ by weight total organic carbon and less than $1 \%$ by weight total suspended solids. This definition has additional exceptions found in 40 CFR 268.2(f) that deal with certain listed wastes that are not applicable to this petition. The SRS Raschig rings do not meet this definition of a wastewater and thus would be subject only to the specified standards for cadmium (D006) characteristic hazardous waste. As such, the SRS Raschig rings are subject to the treatment standards identified in 40 CFR 268.41, Table CCWE (treatment standards expressed as concentrations in the extract) for cadmium waste. 


\subsection{TREATMENT STANDARDS FOR D006 WASTES AND BDAT USED}

EPA originally promulgated treatment standards for characteristic hazardous wastes, including cadmium wastes (D006) as a part of the Third Third rule on June 1, 1990 (55 FR 22520). This rule specified a concentration-based treatment standard of $1.0 \mathrm{mg} / \mathrm{L}$ for D006 wastes in nonwastewater forms of D006. Based on the BDATs that EPA found applicable to D006 wastes and the understanding of the diversity of non-wastewater forms of cadmium wastes, this value was revised to $0.11 \mathrm{mg} / \mathrm{L}$ on August 24, 1998. As discussed in the previous section, the nonwastewater criteria are applicable to the SRS Raschig rings.

In setting the performance standard for D006 at $0.11 \mathrm{mg} / \mathrm{L}$, EPA considered several cadmium waste streams and treatment technologies. For non-wastewater forms of D006, EPA utilized available information on wastes that contained cadmium. The D006 wastes are not readily amenable to recovery processes. The cadmium is presently embedded within the matrix of the Ruschig rings. Recovery processes would also create additional waste that would require disposal as well. 


\subsection{STATEMENT OF THE PETITIONER'S INTEREST IN THE PROPOSED VARIANCE}

This section describes WSRC's intent in seeking a treatability variance for the SRS packing material under 40 CFR 268.44, with respect to the regulatory framework and standards to which the proposed variance applies. The rationale.for the proposed variance is also summarized in this section. A detailed analysis of the waste characteristics relative to the appropriate LDR standards that supports the proposed variance is provided in Sections 5.0 and 6.0 .

\subsection{INTENT OF THE PETITION}

Under 40 CFR 268.44(h), generators and treatment facilities may petition the EPA Regional Administrator for a site-specific variance "where the treatment standard is expressed as a concentration in a waste or waste extract and a waste generated under conditions specific to only one site cannot be treated to the specified level, or where the treatment technology is not uppropriate to the waste." The petition for the site-specific variance must demonstrate that the waste is significantly different from that used to develop the treatment standard. The criteria for demonstrating that a waste is significantly different were addressed in the original promulgation of the LDRs on November 7, 1986 (51 FR 40606), and within 40 CFR 268.44. In order for a waste to be considered significantly different, it must differ from the waste used to establish the CCW or CCWE standard in such a way that:

- It cannot be treated to meet the specified level, or

- The technologies used to establish the treatment level are not appropriate to the waste.

Demonstration that the waste is significantly different may be based upon data that document attempts to treat the waste were unsuccessful or through engineering analysis (51 FR 40606).

WSRC submits this petition to EPA, pursuant to 40 CFR 268.44(h), for a site-specific variance from the treatment standard that is directly applicable to the SRS Raschig rings. The standard specifies a cadmium concentration of less than $0.11 \mathrm{mg} / \mathrm{L}$ in the TCLP leachate for D006 nonwastewaters.

In preparing this petition, WSRC had both a total metals analysis and a TCLP analysis performed. The Raschig rings were found to leach cadmium at a concentration above the regulatory level. WSRC evaluated the physical and chemical properties of the rings relative to the waste and technologies considered within the BDAT basis used to establish the above treatment standard. Based on the results of this engineering analysis, WSRC determined that those technologies considered as BDAT for D006 non-wastewater were inappropriate to the SRS Raschig rings for the following reasons:

- The physical characteristic of the Raschig rings prevents direct application of certain treatment technologies, 
- The D006 BDAT technologies are nol as effective in treating the rings because of their unique physical and chemical characteristics,

- The application of many of the BDAT technologies to the rings will result in the release of other contaminants that must be recaptured, and

- The radiological characteristics of the rings could present an additional risk to personnel who handle the treated and untreated rings.

Furthermore, WSRC is not aware of any treatment technology for the Raschig rings that is currently demonstrated and available. Therefore, WSRC is petitioning EPA for a site-specific treatability' variance from the D006 non-wastewater standard. The proposed alternative standard involves debris-type immobilization of the waste by methods such as encapsulation within a steel jacket or within a polymeric surface coating. Selection of the proposed treatment was based on the following factors:

- The SRS packing material exhibits certain characteristics common to hazardous debris,

- The other debris-type technologies such as physical extraction, chemical extraction, or destruction were considered inappropriate to the Raschig rings, and

- The proposed debris-type immobilization has previously been demonstrated for certain mixed wastes.

EPA has recognized this type of technology (macroencapsulation) as an acceptable method of treating certain debris wastes. A description of the proposed treatment process is provided in Section 7.0 of this petition.

\subsection{SUMMARY OF THE RATIONALE FOR THIS PETITION}

The SRS Raschig rings generated at the H-Area Separations facility have been determined to be characteristically hazardous due to cadmium (D006). These wastes are also contaminated with uranium and fission product isotopes. This petition for a site-specific variance for the SRS Raschig rings from the treatment standards for D006 non-wastewater is submitted on the basis that:

- The technologies considered in the BDAT basis for development of the D006 standard are not appropriate for the SRS Raschig rings because their specific physical, chemical, and radiological properties differ significantly from those of the wastes used to establish the standards, and

- The radiological characteristics of the Raschig rings could present additional hazards that did not exist in the wastes used by EPA to develop the standards. 
Section 6.0 of this petition presents a detailed analysis concerning the applications of D006 BDAT technologies to the Raschig rings. This evaluation demonstrates that these technologies cannot be used to treat the rings because their physical and chemical characteristics make such treatment ineffective or result in the release of additional contaminants. The proposed treatment for the rings involves the use of debris-type immobilization, such as encapsulation of the wastes within a steel jacket or within a polymeric surface coating. A description of the proposed sitespecific alternative standard is provided in Section 7.0 of this petition. 
This page intentionally left blank. 


\section{. 5.0 CHARACTERIZATION OF THE WASTE STREAM}

This section provides a detailed characterization of the Raschig rings generated from the SRS HArea Separations facilities. The physical, chemical, and radiological characterizations are based upon process knowledge and analytical results. Data concerning the historical generation of these wastes are also presented. The data have been used in the engineering analysis prepared in support of this petition, which is presented in Section 6.0.

\subsection{PROCESSES GENERATING WASTE IN HAREA}

Separations processes in $\mathrm{H}$ Area recovered and purified nuclear materials from fuel rods from the SRS production reactors or other outside sources. The initial process in the recovery (or reprocessing) operation involved dissolving the feed material. The resulting solution was then processed through the First Cycle to remove the fission products and other waste materials. The solutions were further processed in the remaining cycles in the facility to separate the nuclear materials for further purification. The solution resulting from the Second Uranium Cycle was a uranyl nitrate hexahydrate (UNH) solution that was transferred outside the 221-H Canyon facility for storage in the H-Area A-Line facility.

During service in the A-Line area, the H-Area Raschig rings were not exposed to caustic process solutions or alkaline vapors. The rings were potentially exposed to UNH solution from the 221H Canyon Second Uranium Cycle, which was stored in tanks in A Line. By H-Area operating procedures, any known spills or leaks of UNH solutions in the A-Line area and B-3 basin were llushed to the appropriate sump and processed through the General Purpose (GP) evaporator to aroid accumulation and possible precipitation. All tanks within the A-Line area are located within secondary containment dikes with sumps for collecting any leaks. Therefore, the Raschig rings in the sumps may have potentially been contaminated with UNH during a spill or release.

Previous operations in the A-Line facility included loading tank trucks with UNH solution for transfer to Oak Ridge for further processing. When these shipments were ceased, the Enriched Uranium Storage (EUS) tank was constructed for long-term storage of the uranyl nitrate solution. Leaks or spills that occur from the EUS tank enter the spill containment annulus and are then returned to the tank by the annulus pump after sampling. With the EUS tank recycling its own leaks, the Raschig rings were no longer necessary and were removed.

\subsection{CHARACTERISTICS OF THE WASTE MATRIX}

This section characterizes the Raschig rings with respect to those waste constituents that are present in the internal matrix or upon the exterior surface of the rings. These constituents include the cadmium, lead and other trace metals dispersed within the rings during manufacture and any products collected on the rings during service. Additionally, the chemical characteristics contributed by the fission product isotopes and decay products are addressed. 


\subsubsection{Chemical Characteristics of the SRS Raschig Rings}

The Raschig rings were sampled and analyzed in March and May 1999. Analytical results showed the Raschig rings are composed of a mixture of metals dispersed throughout an organic matrix. The primary metals in the rubbery plastic matrix are cadmium (approximately $20 \%$ by weight) and lead (approximately $20 \%$ by weight). The cadmium acts as the neutron absorber, and the lead increases the specific gravity to prevent the rings from floating in high-density solutions. Other trace metals were also detected.

The metal mixture is dispersed throughout the rubbery plastic matrix of the Raschig ring. In this encapsulated state, it is unlikely that the rings from H-Area A-Line sumps would threaten human health. The results of the TCLP showed the lead and trace metals were below regulatory levels, but cadmium was detected above the regulatory level. Therefore, SRS is addressing the waste as D006 in this petition.

\subsubsection{Radiological Characterization of the SRS Raschig Rings}

Specific historical radiological characterization data are not available for the H-Area A-Line sump Rischig rings. The rings were located in A-Line sumps and were in contact with minor process leaks and rainwater runoff during their service. The contamination by radionuclides occurred during the collection of these minor leaks or spills in the A-Line sumps. Because the solutions collected in the sump were primarily rainwater, they were processed through the General Purpose (GP) evaporator and no radiological characterization data was maintained on the sump solutions.

A radiological screening analysis for alpha, beta, and tritium activity was performed on a representative sample containing 21 Raschig rings in 1995. Analysis indicated low levels of radioactivity. The presence of radioactive materials makes the Raschig rings a mixed waste. Though levels are very low, there still exists the potential for exposure to some radioactive materials during sampling and packaging activities. Because of the geometry of the Raschig rings, successful decontamination would be difficult. Therefore, radioactivity will be considered in addressing the wastes in this petition.

\subsection{W'ASTE GENERATION}

The rings were used in $\mathrm{H}$-Area A-Line sumps as a criticality contingency measure to prevent the accumulation of a critical mass of material in the sumps. The rings were generated one time only. The storage facilities have been modified, and the new EUS tank constructed. Therefore, the Raschig rings are no longer used and will not be generated in the future.

The removal of the Raschig rings generated $1.8 \mathrm{~m}^{3}$ of material, which is currently in storage. These wastes resulted from a single clean out of A-Line sumps in 1992. The Raschig rings generated in $\mathrm{H}$ Area are currently contained within plastic bags inside drum liners and stored in a total of nine loosely-packed 55-gallon drums. 


\subsection{DEMONSTRATION THAT THE SRS RASCHIG RINGS DIFFER \\ SIGNIFICANTLY FROM THE WASTES USED TO SET THE TREATMENT STANDARDS}

This section is a technical evaluation of the SRS waste with respect to the waste and BDAT used to set the treatment standards for D006 characteristically hazardous waste. Under $40 \mathrm{CFR}$ 268.44(h), a petitioner may be granted a site-specific treatability variance from those standards promulgated as $\mathrm{CCW}$ or CCWE if it can be demonstrated that the petitioner's waste differs significantly from those used to develop the standard.

\subsection{WASTE COMPOSITION}

Previously, the cadmium and lead concentrations in the Raschig rings have been estimated based on knowledge of the process conditions. Recent analytical results show that the Raschig rings contain approximately $20 \%$ cadmium that acts as the neutron absorber, and approximately $20 \%$ lead that adds weight to the rings to keep them from floating in a dense solution. The cadmium and lead are dispersed throughout a rubbery plastic matrix, which encapsulates the cadmium and lead within the matrix of the rings. Other trace metals are also dispersed throughout the organic matrix.

A TCLP analysis was performed on the Raschig rings in May 1999. The tests revealed the following constituents and the respective concentrations in the waste matrix. Cadmium, with a concentration of $7.27 \mathrm{mg} / \mathrm{L}$, exceeded the $1.0 \mathrm{mg} / \mathrm{L}$ limit. All other constituents fell below regulatory levels.

Table 6-1 TCLP Metals Analysis Results

\begin{tabular}{|c|c|c|c|}
\hline Parameter & Qualifier & Result & Units \\
\hline Arsenic & $\mathrm{U}$ & 0.0148 & $\mathrm{mg} / \mathrm{L}$ \\
\hline Barium & $\mathrm{J}$ & 0.0155 & $\mathrm{mg} / \mathrm{L}$ \\
\hline Cudmium & & 7.27 & $\mathrm{mg} / \mathrm{L}$ \\
\hline Chromium & $\mathrm{U}$ & 0.00239 & $\mathrm{mg} / \mathrm{L}$ \\
\hline Lead & & 4.13 & $\mathrm{mg} / \mathrm{L}$ \\
\hline Mercury & $\mathrm{J}$ & 0.000576 & $\mathrm{mg} / \mathrm{L}$ \\
\hline Selenium & $\mathrm{U}$ & 0.00335 & $\mathrm{mg} / \mathrm{L}$ \\
\hline Silver & $\mathrm{U}$ & 0.000740 & $\mathrm{mg} / \mathrm{L}$ \\
\hline $\begin{array}{c}\text { The qualifiers defined in this report are defined as follows: } \\
\text { J indicates presence of analyte at a concentration less than the reporting limit and greater than the } \\
\text { detection limit. } \\
\text { U indicates that the analyte was not detected at a concentration greater than the detection limit. }\end{array}$ \\
\hline
\end{tabular}


The criteria identified under 40 CFR 268.44 are used to demonstrate that a given waste stream is significantly different from those used to establish the standards. Additionally, EP.A has addressed the criteria in a number of Federal Register notices (see 51 FR 40606, 54 FR 48376). The criteria are as follows:

- Subject waste stream cannot be treated to meet the specified CCW or CCW standard.

- Evaluation of the SRS Raschig rings will demonstrate that due to the unique physical, chemical, and radiological properties of the rings, the BDAT used to set the standards are inappropriate for this waste.

Section 6.2 provides the evaluation of the various BDAT treatments used to develop the DUU0 standard with respect to the SRS Raschig rings.

\subsection{EVALUATION OF THE SRS RASCHIG RING WASTE WITH RESPECT TO THE D006 STANDARD}

Linder the Third Third Rule, EPA promulgated a treatment standard for D006 non-wastewater of $0.11 \mathrm{mg} / \mathrm{L}$ in the TCLP leachate. The BDAT background document used in the evaluation uses $1.0 \mathrm{mg}: \mathrm{L}$ TCLP as the treatment standard. In the BDAT background document that established the treatment standard, EPA indicated that limited data exist on treating elemental cadmium waste contaminated with radiological constituents. There is no conclusive data that show cadmium can be separated from the radioactive material. Therefore, the waste will not require separation of radioactive material from the waste matrix, but will be treated as a mixed waste.

Radioactively hazardous mixed wastes are subject to the treatment standards in 40 CFR 268.40. Ithere treatment standards are specified for radioactive mixed wastes in the Table of Treatment Standards. those treatment standards will govern. Where there is no specific treatment standard for radioactive mixed waste (as in the waste subject to this petition), the treatment standard for the hazardous waste applies. Hazardous debris containing radioactive waste is subject to the treatment standards specified in 40 CFR 268.45.

The SRS spent Raschig rings are a non-wastewater form. In the BDAT background document that established the treatment standard, EPA indicated that limited data were available concerning the treatment of D006 wastes. In establishing the treatment standard for D006 nonWustewaters, EPA considered two subcategories: (1) cadmium batteries, and (2) other cadmium non-wastewaters. The following treatment technologies were evaluated as BDAT for these Mastes:

- Stabilization (other than cadmium-containing batteries),

- High temperature metals recovery,

- Chemical precipitation,

- Incineration, and

- Cadmium recovery (from batteries). 
In determining. whether treatment is substantial, EPA may consider data on the performance of a waste similar to the waste in question, provided that the similar waste is at least as difficult to treat. The most desirable waste management technology is one that results in no residual streams or a residual stream with no hazardous properties.

The remainder of this section presents an engineering evaluation of the SRS Raschig rings relative to the wastes and BDAT used to set the D006 standards. This analysis will demonstrate that the BDAT are inappropriate to the rings because of their unique physical, chemical, and radiological properties.

\subsubsection{Stabilization}

In the background document for D006 wastes, one technology considered as BDAT for D006 non-wastewaters (other than cadmium-containing batteries) is stabilization of cadmium. EPA noted that cadmium may be present in certain waste forms from which it is not readily extracted or amenable to recovery. Stabilization technologies involve immobilization of hazardous constituents through the use of certain agents that react with the constituent to reduce its solubility and chemically bind it within a solid matrix. The technology is typically applied to metal-bearing sludges to reduce their leachability. The hazardous constituents are mixed with binders, such as lime, fly ash mixtures, cement, or concrete mixtures. Water is then added, and the mixture sets into a solid mass that can be land disposed.

In the BDAT background document for D006 waștes, EPA reported testing cement, kiln dust, and lime/lly ash binders for stabilization of cadmium-containing wastes. Based on the results of these tests, EPA determined that lime/fly ash was the most successful stabilization agent for reducing the TCLP leachate concentration of cadmium. Three sets of performance datal for stabilization of cadmium-containing waste with lime/fly ash were presented in the background document. These data indicated an average cadmium concentration (as K061 waste) in the untreated waste of $481 \mathrm{mg} / \mathrm{kg}$. The average cadmium concentration in TCLP extract from the untrcated waste was $12.8 \mathrm{mg} / \mathrm{L}$. After stabilization, the cadmium concentration in the TCLP leachate from the test samples was $0.033,0.049$, and $0.073 \mathrm{mg} / \mathrm{L}$, respectively. These test sumples indicated an average reduction in the TCLP extract cadmium concentration of 12.748 $\mathrm{mg} / \mathrm{L}$. The TCLP leachate concentrations are below the standard of $0.11 \mathrm{mg} / \mathrm{L}$.

Stabilization has been used on a commercial basis to treat the listed wastes K061 and F006. Some F006 wastes contain high levels of cadmium, particularly if they originate from electroplating operations producing cadmium-coated products. The commercial use of stabilization to treat F006 wastes is described in the F006 background document (USEPA 1988b).

Performance data for treatment of cadmium-containing non-wastewaters using stabilization have been provided by EPA. The treatments used are discussed in detail in the $\mathrm{KO} 0 \mathrm{l}$ background document (USEPA 1988a). The EPA also has stabilization performance data from two iron foundries. These foundry wastes contain both lead and cadmium as hazardous constituents. Several stabilization formulations reduce both the lead and cadmium EP toxicity test leachates to below characteristic levels. The foundry wastes are likely to be different to treat than K00I and 
F006 cadmium-containing wastes because of the different raw waste lead and cadmium mixture present. Data collected demonstrates that stabilization mixtures can reduce cadmium levels present in leachate to below characteristic levels.

The chemical characteristics of the SRS Raschig rings differ significantly from the wastes considered in establishing stabilization as.BDAT. The concentration of cadmium in the Raschig rings is approximately $194,000 \mathrm{mg} / \mathrm{kg}$. The TCLP extract concentration of cadmium was determined to be $7.27 \mathrm{mg} / \mathrm{L}$. Since the Raschig ring material is homogeneous, the cadmium concentration is as well. Stabilizing the rings, even if they were size reduced, would not appreciably reduce the leachability of a crushed sample. Therefore, stabilization is less likely to be successful with the Raschig rings than the waste streams considered in the BDAT determination.

\subsubsection{High-Temperature Metal Recovery}

There are two types of high-temperature metals recovery operations in use for reclamation of cadmium from wastes. The first type is used at commercial primary zinc smelters, which accept "astes with high concentrations of cadmium and zinc sulfides. These wastes are blended with sulfide ores and fed to reverberatory furnaces along with coke. Zinc and cadmium metals volatilize from the roasting operation and are collected together by condensation. The crude zinc is then reined electronically to separate the cadmium, which is recovered separately as the metal.

Commercial smelters generally accept cadmium- and zinc-bearing residues whose content is similar to that of the ores normally processed. These facilities normally blend the residues with purchased ore prior to processing. Use of residuals with cadmium and zinc concentrations different from normally used feed materials requires process modifications. For this reason, high-temperalure metals recovery using smelters is limited in the types of wastes it can treat.

The second form of high-temperature metals recovery in use for waste treatment is a modification of the standard process for production of zinc oxide. In this process, the waste is blended with coke, silica, and lime and fed to a high-temperature furnace. Chemical reactions occur between the zinc and cadmium sulfides present, oxygen, and carbon to form elemental zinc and cadmium. For cadmium, these reactions are:

$$
\begin{aligned}
& 2 \mathrm{CdS}+3 \mathrm{O}_{2} \rightarrow 2 \mathrm{SO}_{2}+2 \mathrm{CdO} \\
& 2 \mathrm{CdO}+\mathrm{C} \rightarrow 2 \mathrm{Cd}+\mathrm{CO}_{2}
\end{aligned}
$$

Elemental zinc and cadmium volatilize and react with oxygen to re-form the oxides. The oxides are then collected from the hot gases emerging from the furnace in the baghouses. The impure zinc oxide generated is then purified to separate out cadmium, which is recovered and purified. High-temperature metals recovery is discussed in the Treatment Technology Background Document (USEPA 1989b).

The EPA has 11 data sets for treatment of K061 waste by high-temperature metals recovery. Seven of the data sets represent data that the EPA collected on a rotary kiln unit; the others 
included data from a plasma arc furnuce and a molten slag reactor. Treatment for the waslewalter is described in detail in the background document for K061 wastes (USEPA 1988a).

For high-temperature metals recovery, treatment performance is measured by the reduction in the concentration of metal constituents from the untreated waste and also the reduction of leachability of the metals in the residual as compared to the untreated waste. EPA has been unable to quantify a recoverable concentration for cadmium, but believes that recovery is demonstrated for treatment of all wastes in the Industrial Cadmium Batteries Subcategory.

High-temperature metals recovery (HTMR), such as is demonstrated for treatment of K061. wastes, is also demionstrated for non-wastewaters. As a recovery technology, this is the preferred and best technology for treatment of wastes with high cadmium concentrations. The HTMR' residuals will contain much lower concentrations of cadmium than does the untreated waste.

The waste subject to this petition contains approximately $20 \%$ cadmium metal dispersed throughout a rubbery plastic matrix. However, the presence of radioactive contamination poses a problem with high temperature recovery. Though contamination is low, there exists the potential for a release of radioactive materials into the off-gases. Therefore, high temperature metal recovery is not appropriate for this waste.

\subsubsection{Chemical Precipitation}

Chemical precipitation technologies are normally used to treat wastewaters. Chemical precipitation may' also be used to treat dilute suspensions of solids in water. This technology Iypically involves the addition of lime, caustic, or a sulfide compound to the solution with $\mathrm{pH}$ adjustment. Cadmium hydroxide or cadmium sulfide precipitates from the solution and is collected by filtration. The collected solids are treated by high-temperature metals recovery or stabilization prior to disposal. The treated solution may be further treated or discharged.

Chemical precipitation is not an appropriate treatment technology for this waste. The spent Ruschig rings are an insoluble, non-wastewater form.

\subsubsection{Incineration}

Incineration is applicable to treatment of D006 wastes containing organics. Incineration treatment destroys the organic compounds contained in the wastes. During incineration, some of the cadmium present in the waste volatilizes and is removed as the metal or the oxide in the scrubber water; the rest remains in the solid residue (ash). The residuals (scrubber water and ash) can be treated by the technologies applicable to treatment of wastewaters and non-wastewaters containing no organics.

Incineration is demonstrated for treatmen! of many hazardous wastes containing organic and metal constituents. These incineration processes generate scrubber wastewaters and ash that may contain one or more toxic metal constituents which, if they contain cadmium above characteristic levels, must be managed as D000 wastes. 
The only incinerator currently available to treat radioactive waste contaminated with RCRA metals, the Consolidated Incinerator Facility (CIF), is located at SRS. Incineration followed by stabilization would be appropriate for the waste subject to this petition. However, the cadmium content of the Raschig rings exceeds the acceptance criteria of the CIF. Thus, incineration is not available as a treatment technology for this waste.

\subsubsection{Cadmium Recovery (from batteries)}

Cadnium recovery has been identified as an applicable technology for treatment of cadmiumcontaining battery. wastes. Cadmium may be recovered from these wastes using pyrometallurgical techniques or smelting techniques.

The cadmium recovered from batteries is significantly different from the cadmium in the Raschig rings. The cadmium in the rings is embedded throughout the ring matrix. Therefore, this lechnology is not applicable to this waste. 


\subsection{PROPOSED ALTERNATIVE STANDARD AND TREATMENT PROCESS}

Based on the engineering analysis presented in Section 6.0, the technologies considered as BDAT in setting the treatment standard for D006 non-wastewater described in Section 6.2 are not appropriate to the SRS Raschig rings because of their unique physical, chemical, and radiological characteristics. Furthermore, SRS is not aware of any technology that is currently demonstrated and available for treatment of these wastes. Accordingly, SRS is petitioning EPA to establish a site-specific, technology-based treatment standard for the rings. The basis for the site-specific standard and the proposed treatment process selected are described in this section.

Although the Raschig rings are considered to be a spent material and are not considered to be hazardous debris because of their size, the waste shares certain similarities with materials commonly considered to be hazardous debris. The Raschig rings are within 5 to $10 \mathrm{~mm}$ of the 60 $\mathrm{mm}$ criterion. Consistent with the definition of hazardous debris, the rings are manufactured objects constructed of a mixture of metals in a rubbery plastic matrix and are solid in physical form. In promulgating the Debris Rule, EPA indicated that the debris treatment standards were applicable to debris that contained hazardous wastes either on the debris surface or within its

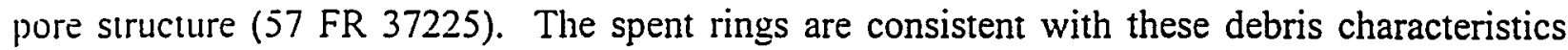
because the hazardous constituent is dispersed throughout the rubbery organic matrix. Furthermore, in the preamble to the Debris Rule, EPA indicated that discarded industrial equipment (i.e., pumps, filters) was considered debris even if the waste resulted from a waste treatment process. Therefore, the characteristics of the Raschig rings are generally consistent with the definition and interpretive policy concerning the nature of materials that may be considered hazardous debris except for the debris size criterion.

As a result of the similarity between the characteristics of the Raschig rings and material generally considered to be hazardous debris, SRS considered the application of debris-type technologies for treatment of them. In the final rule, EPA classified debris-type treatment technologies within the following categories:

- Physical extraction, .

- Chemical extraction,

- Thermal extraction,

- Biodegradation,

- Chemical oxidation,

- Thermal destruction, and

- Immobilization processes.

Physical extraction technologies include processes such as abrasive blasting, scarification, grinding, and spalling. For melal debris, the performance standard for physical extraction technologies requires removal of contamination and treatment to a "clean debris surface". A clean debris surface means the surface, when viewed without magnification, shall be free of all visible contaminated soil and hazardous waste except that residual staining from soil and waste consisting of light shadows, slight streaks, or minor discoloration. Soil and waste in cracks, crevices, and pits may be present.but shall be limited to no more than $5 \%$ of each square inch of 
surface area.. These treatment processes are considered inappropriate to the Raschig rings because cadmium is embedded within the matrix of the rings, not just on their surface.

Chemical extraction technologies, including processes such as acid leaching, solvent extraction, and aqueous extraction, are designed to clean the surface of the debris (see 40 CFR 268.45, Table 1). As stated in Section 6.2.1, the waste subject to this petition is homogeneous; surface cleaning, no matter how aggressive, will not reduce the RCRA -toxic characteristic of the Raschig rings. Thermal extraction technologies include high-temperature metals recovery and thermal desorption processes. These treatment processes were also demonstrated to be inappropriate for the rings.

Biodegradation and thermal destruction by incineration are considered inappropriate for treating the Raschig rings because the hazardous metal constituent dispersed throughout the rubbery' matrix is inorganic in nature. Chemical oxidation processes and certain types of chemical reduction processes such as electrolytic precipitation and metallic replacement are also inappropriate for the rings since they are insoluble solids. Furthermore, application of chemical reduction processes for treatment of hazardous constituents dispersed throughout the ring matrix has not been demonstrated. If chemical reduction were applied directly to the constituents within the rings, it is likely that sufficient residual cadmium would be present in the treated waste to yield a TCLP extract concentration above the treatment standards. Therefore, the only debristype technologies considered potentially appropriate to the Raschig rings are the immobilization processes.

This trealability variance petition proposes a site-specific treatment standard for the Raschig rings based on debris-type immobilization. This waste treatment method is consistent with the overall objectives of the LDRs, which require EPA to promulgate treatment standards that substantially diminish the toxicity of the waste or reduce the likelihood of migration of hazardous constituents. Treatment of the SRS rings by the proposed immobilization process will substantially reduce the probability for migration of the hazardous and radioactive constituents by preventing contact between any potential leaching media and the surface of the wastes.

SRS considered various immobilization treatment options (macroencapsulation, microencapsulation) for the waste subject to this petition. (Sealing was also evaluated, but given the small size and surface geometry of the rings, it was not considered appropriate.) The selection of a particular immobilization technology will be based on the following design criteria:

1. The immobilizing material must be resistant to degradation by environmental conditions and media.

2. The immobilizing material must be radiologically stable and resistant to degradation by the waste constituents.

3. The design must provide shielding, as necessary, to safely handle the waste form and comply with ALARA principles and SRS personnel exposure limits. 
4. The final waste form must be structurally sound.

SRS considered various materials to meet the design criteria given above. Steel, concrete. and various polymers were considered the best candidate materials because of their common use for this purpose and their chemical and radiological stability in various applications in the chemical and nuclear industries. Detailed discussions of the various options are included in the following sections.

\subsection{ENCAPSULATION WITHIN A CEMENT MATRIX}

Direct encapsulation of the waste within a portland cement matrix has been considered as an option for the proposed treatment process. In 'general, cured cement is relatively inert chemically' and has a radiation threshold (the total dose received without significant chemical, physical; or mechanical deterioration) of $10^{\prime \prime} \mathrm{rem}(\mathrm{R})$. Additionally, cement was considered to provide sufficient structural strength for the final waste form, and by controlling the waste/cement ratios the dimensions and mass of the final form may be constrained within readily handled limits.

This option could involve one of two approaches: dispersion of the individual waste forms within the matrix (microcncapsulation, as defined in 40 CFR 268.45, Table 1, Section C.2) or placement of waste containers within a cement matrix that was allowed to cure and encapsulate the waste (macroencapsulation, as defined in 40 CFR 268.45, Table 1, Section C.1).

When assessing the dispersion of the individual waste forms within the cement matrix, interaction between the waste and cement was considered. The rings contain cadmium and a variety of radionuclides that may be present as uranyl nitrates. These species may interfere with the setting and curing of portland cement. Furthermore, the performance standard for microencupsulation is the same as for stabilization: the leachability of the target constituent must be reduced. As indicated previously in Section 6.2.1, this is unlikely to be successful, so this option must be eliminated.

When evaluating encapsulation of the containerized waste within a cement matrix (macroencapsulation), the resistance of concrete to environmental media and conditions was compared to that of the other candidate encapsulating materials. The primary environmental degradation mechanisms for concrete include cracking due to freeze-thaw cycles, sulfate attack, .water permeation, and chloride ion penetration. Additionally, shrinkage during curing, resulting in surface cracking, is an inherent property of concrete. Although each of these potential disadvantages may be controlled or overcome by air entrainment, the use of sulfate-resistance portland cement, incorporation of various additives, and control of the mix, concrete was considered more susceptible to envirommental degradation that the other candidate encapsulating malerials. Nevertheless, it is an appropriate encapsulant for the waste subject to this petition, assuming that requisite handling of the waste during the treatment process does not violate ALARA principles. 


\subsection{ENCAPSULATION WITHIN A POL YMER MATRIX}

Direct encapsulation of the waste within a polymeric matrix has been considered as an option for the proposed treatment process. As in the preceding case, this option may be implemented by dispersion of the waste forms within a polymeric matrix or polymeric surface-coating and encapsulation in an approved container.

The most common processes for fabrication with thermoplastics are compression molding. injection molding, blow molding, rotational molding, colandering, hand lay-up, and casting. Processes commonly used for fabrication with thermosetting resins include compression and injection molding, hand lay-up, casting, and filament winding. Blow molding, rotational molding, and colandering are used to fabricate hollow objects or sheet stock and are not suitable for this application. Hand lay-up techniques are labor intensive, requiring prolonged exposure of personnel to containers of waste. Although compression molding, injection molding and nilumeni winding might be applied to encapsulation of the containerized waste, significant difficulties related to maintaining the polymer in fluid state and the probable uneven distribution of the waste within the containers would have to be overcome.

Accordingly, casting was considered the preferred technique for the polymer encapsulation option. In this process, the containerized waste would be placed within an approved container, and molten thermoplastic or partially polymerized thermosetting resin would be pumped into the space to completely surround the waste container. The container would then be permanently sealed.

In yeneral, the majority of polymers are not subject to degradation by environmental conditions and media, with the exceptions of ultraviolet degradation of thermoplastics and freeze-thaw cracking of certain rigid plastics.

Direct encapsulation of the waste within a polymeric matrix or polymeric-type surface coating is considered appropriate treatment for the waste assuming that handling of the waste that would be required for dispersion of the waste in the matrix complies with ALARA principles.

\subsection{IMIMOBILIZATION WITHIN A STEEL JACKET}

Macroencapsulation of the containerized waste within an inorganic jacket, such as steel, has also been considered as an option for the proposed treatment process. This technology provides superior structural integrity and is highly resistant to environmental degradation. The container must be capable of being sealed permanently, and shall provide the necessary structural strength for waste handling and transport. Containers constructed from steel alloys have been previously demonstrated to comply with the mechanical integrity requirement for transport of radioactive waste, and fitting devices may be fabricated in the jacket to provide for ease of handling of the final wasle form. 
Furthermore, steel is reșistant to the environmental conditions that will be encountered. A literature search conducted at SRS indicates steady state atmospheric corrosion rates of carbon steel to be on the order of 0.001 in./yr for conditions at SRS. At this rate, 3/8-in. carbon steel will not be penetrated in 375 years. The corrosion data are for steel that is not in contact with water. The outer surface of the jacket may be coated, depending on its storage location, so that the steel does not contact water. The lid for the container will be designed to create a permanent seal, with a locking mechanism and a long-lived polymeric gasket.

The only residuals from the treatment process are the immobilized waste packages. The characteristics of the immobilized waste, described in Section 5.0, will not be altered by the treatment process. However, the immobilization process will substantially reduce the potential for migration of the hazardous and radioactive constituents by sealing the waste within a jacket or drum of inorganic material that is resistant to degradation from the waste constituents and the external environment. The proposed treatment encapsulates the waste package in a container of inert inorganic material that is equivalent to the alternative treatment standards of $40 \mathrm{CFR}$ 208.42 .

The proposed site-specific treatment standard for the Raschig rings has been previously demonstrated and accepted by EPA as an effective treatment for similar wastes. Macroencapsulation of certain mixed low-level radiological waste generated by the U.S. Navy by placement of the wastes within a stainless steel jacket was the basis for EPA specifically including the use of inert inorganic jacketing materials within the definition of this treatment standard. Additionally, in the response to comments for the hazardous debris rule, EPA indicated that debris-type macroencapsulation included the use of sealed containers that met the performance standards. 
This page intentionally left blank. 


\subsection{SUMMATION AND FORMAL REQUEST}

This section summarizes the process that generates the waste stream, the waste characterization, and the treatment technologies applicable to the Raschig rings. The section also formally requests a treatability variance for the SRS Raschig ring packing material.

\subsection{SUMNATION}

When in full operation, SRS produced nuclear material by manufacturing fuel and target components that were then irradiated in nuclear reactors. The fuel and target. components were manufactured in $\mathrm{M}$-Area and were then transferred and loaded into production reactors in $C, K$, L. P, and $R$ Areas. Once irradiated, the fuel rods and targets were transported by shielded railroad cars to either $\mathrm{F}$ or $\mathrm{H}$ Area for recovery of nuclear materials.

Liquid-liquid extraction and purification of the desired nuclear materials from the irradiated fuel rods and targets were performed at the Separations facilities in $F$ and $H$ Areas. The primary nuclear materials products obtained from the Separations facilities were Pu-239 and U-238. These products were obtained by dissolving irradiated depleted uranium targets or plutonium aluminum alloy charges in nitric acid, followed by separation of the desired materials using the Plutonium Uranium Extraction (PUREX) process. The initial stages of this process involved a series of contactors that provided separation of the uranium and plutonium from the "Iaste activation and fission product isolopes. Subsequent stages of the PUREX process separated plutonium from the uranium and purified both product streams. The product streams were either transferred to other DOE facilities for further processing or returned to $M$ Area for reuse in turget fabrication.

The PUREX process was modified (and named HM acronym for "H modified") to limit the concentrations of the uranium product beculuse the available facilities were not geometrically favorable for nuclear criticality control when dealing with large quantities of enriched uranium. Using this modified process, the H-Area Separations facility recovered enriched U-235 from spent fuel rods generated in the production reactors by dissolution in nitric acid followed by separation of U-235 from the waste fission products. After the dissolution, the materials were processed through the initial steps of the HM process that removed the fission products and other waste materials. Depending on the source of the material, the remaining steps of the process were completed as necessary. One part of the process was the Second Uranium Cycle and was where the uranyl nitrate hexahydrate (UNH) solution was produced. The UNH solution was then transferred from the 221-H Canyon outside to the A-Line facility.

Several sufety features were incorporated in $\mathrm{H}$ Area when the Separations facility was converted from PUREX to HM, including the removal of equipment and pipe connections that could contribute to inadvertent transfers of materials. In addition, because the H-Area A-Line sumps were not critically safe in configuration, the sumps were packed with neutron-absorbing Ruschig rings made of a mixture of metals dispersed within an organic matrix. Any known spills or leaks of uranyl nitrate solutions in the A-Line area and B-3 basin were flushed to.the appropriate sump 
and processed through the General Purpose (GP) evaporator to avoid accumulation and possible precipitation.

The spent Raschig rings are characteristically hazardous for cadmium (D006), and are potentially' radioactively contaminated with uranium, plutonium, and various other isotopes. Based on analytical data, the rings contain sufficient cadmium to yield a TCLP leachate in excess of the characteristic level.

SRS conducted an engineering evaluation to determine the appropriateness of those technologies considered as BDAT in setting the treatment standards for D006 non-wastewaters for treating SRS Raschig rings. The technologies considered as BDAT for D006 non-wastewaters were stabilization (other than cadmium-containing batteries), high temperature metals recovery, chemical precipitation, incineration, and cadmium recovery (from batteries).

The technologies listed above are inappropriate to the Raschig rings for several reasons:

- The physical, chemical, and radiological characteristics of the rings differ significantly from the wastes considered in establishing stabilization as BDAT. The spent rings are composed of cadmium dispersed throughout a rubbery plastic matrix and are contaminated with low levels of radioactive materials. Stabilization of the waste would not reduce the leachability of the cadmium to the environment.

- The cadmium is embedded in the matrix of the rings, and would require the use of a higher operating temperature for removal or recovery. There is no incinerator permitted to accept radioactive waste contaminated with the level of cadmium in the Raschig rings.

- The Raschig rings are contaminated with low levels of radioactive materials. Thermal or chemical treatments will generate residues contaminated with various radionuclides, which would have to be managed as mixed wastes.

SRS investigated the application of hazardous debris technologies (physical extraction, chemical extraction, destruction, and immobilization) for treatment of Raschig rings because they exhibit certain debris-like characteristics. Consistent with the definition of hazardous debris (57 FR 37225 ), the rings are manufactured objects constructed of metals in a plastic matrix that is solid in physical form. Furthermore, the hazardous constituent is dispersed within its plastic matrix.

Physical extraction, chemical extraction and destruction technologies for debris waste were determined to be inappropriate because of the physical and chemical characteristics of the rings. Immobilization technologies were evaluated and found to be appropriate for the waste. The performance standards for macroencapsulation can be achieved by either application of a polymeric coating or the use of an inorganic jacket. 
The encapsulated material will be placed in an approved steel or plastic container and sealed shut. The integrity of the macroencapsulation will be ensured by constructing or applying it in accordance with nationally recognized standards, conducting a non-destructive inspection of the macroencapsulation after fabrication or application, and strict adherence to QA/QC procedures. The encapsulating materials will be resistant to degradation by environmental conditions and the constituents present in the waste.

\subsection{FORMAL REQUEST.}

The U.S. Department of Energy, Savannah River Operations Office formally requests that EPA approve this site-specific variance from the LDR treatment standard for D006 non-wastewater for the Raschig rings. The waste will be immobilized using a debris-type encapsulation in a steel jacket or polymer-type surface coating. The waste will be disposed in an approved steel or plastic container. 
This page intentionally left blank. 


\section{$9.0^{\circ}$ CERTIFICATION}

I certify under penalty of law that I personally examined and am familiar with the information submitted in this petition and all attached documents, and that based on my inquiry of those individuals immediately responsible for obtaining the information, 1 believe that the subimitted information is true, accurate, and complete. I am aware that there are significant penalties for submitting false information, including the possibility of fine and imprisonment.

Westinghouse Savannah River Company as Co-Operator

Date W.S.J. Kelly, Vice President and General Manager

Solid W'aste Division 
This page intentionally left blank. 


\subsection{REFERENCES}

Federal Register. Land Disposal Restrictions for Nenly Listed Wastes and Hazardous Debris Rule. 57 FR 37194 et seq. (August 18,1992).

Federal Register. Land Disposal Restrictions for "Third-Third" Schedule H'astes Final Rule. 55 FR 22520 et seq. (June 1,1990).

Final Response to Comments on Proposed Rule for Hazardous Debris. CD 2P-00007 et seq. (June 29,1992).

Perry and Chilton. Chemical Engineers Handbook. $5^{\text {tht }}$ ed., McGraw Hill Book Company; New lork (1973).

Hestinghouse Savamnah River Company. Savannah River Site Approved Site Treatment Plan. lyys Annual Uipclate. (March 16, 1998).

Westinghouse Savannah River Company. Treatability Variance for Silver-Coated Packing Malerial. (July 1997).

Westinghouse Savannah River Company. Treatability Variance for Tritiated Water with Morcur): (June 1997).

LSDOE Environmental Guidance Division. Obtaining Variances from the Treatment Standards of the RC'RA Land Disposal Restrictions. (May 1990).

L'SEPA 1988a. U.S. Environmental Protection Agency, Office of Solid Waste. Best Demonstrated Available Technolog.' (BDAT) Background Document for K061.

USEPA 1988b. U.S. Environmental Protection Agency, Office of Solid Waste. Best Demoinstrated Available Technology' (BDAT) Background Document for F006.

USEPA 1989. U.S. Environmental Protection Agency, Office of Solid Waste Treatment Technolog.' Background Document.

USEPA 1991. U.S. Environmental Protection Agency, Office of Solid Waste. Treatment Engineering Bulletin Stabilization/Solidificution. EPA/000/0-00/000 (November 1991).

Waste Stream Questioṇnaire - 1993, SR-W073 (May 16, 1994).

Weast, Robert C. Handbook of Chemistry' and Physics. 56"' ed., CRC Press (1975). 
This page intentionally left blank.

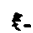

